\title{
Comparative Study of Banks in the Perspective of Syafruddin Prawiranegara and M. Syafii Antonio
}

\author{
Muhammad Amin Azis*, Muhsin Hariyanto \\ Universitas Muhammadiyah Yogyakarta, Indonesia
}

Article History

Received: December, $15^{\text {th }} 2021$ Revised: December, $13^{\text {th }} 2021$ Accepted: January, $13^{\text {th }} 2022$

\begin{abstract}
${ }^{*}$ Corresponding

author:

E-mail:

aminazis256@gmail.c $\underline{\mathrm{om}}$

The Law of Bank Interest is a complicated issue in Islamic economics because there are differences of opinion among Muslim scholars and intellectuals. This can not be separated from the observations of Indonesian Muslim economists such as Syafruddin Prawiranegara, who thinks bank interest is permissible, while M. Syafii Antonio believes bank interest is haram (forbidden in Islam). This research is entitled "Comparative Study of Banks in the Perspective of Syafruddin Prawiranegara and M. Syafii Antonio". This study aims to determine the views of Syafruddin Prawiranegara and M. Syafii Antonio regarding bank interest and examine the differences, similarities and backgrounds of their opinions. This type of research is library research with qualitative methods. The data analysis technique was carried out by means of deductive-comparative, in which this research first explains the arguments of the two figures regarding usury and bank interest then compared with the comparative method. The results of this study are 1. Syafruddin Prawiranegara believes Interest cannot be equated with usury. According to him, the difference of opinion regarding bank interest is due to a misinterpretation of the function of money. 2. M. Syafii Antonio is of the opinion that the law of bank interest is the same as usury. To stipulate the law on interest, it is necessary to comprehensively understand the stages of the derivation of the verses of usury. 3. The difference of opinion between the two is seen from the results of ijtihad (making a decision based on Islamic law) and the istinbath methods.
\end{abstract}

Keywords: Bank Interest, Usury, Syafruddin Prawiranegara and M. Syafii Antonio 


\section{Introduction}

\subsection{Background}

As social beings, humans cannot be separated from their economic activities to meet their daily needs. Economic practice is the most basic thing that humans continue to do in their daily lives. The development of an increasingly advanced era affects the economic practices carried out by the community, which are increasingly developing with increasingly diverse economic patterns. The development of the times also demands the establishment of economic institutions or agencies that support the community's economy, such as online markets, online credit and lending, banks (financial institutions) and humanitarian institutions (philanthropy).

Banks are financial institutions that support the economic development of the community and are then responsible for managing customer savings. When managing a bank (financial institution), it must be based on the value of honesty as the basis for attracting public trust to save in financial institutions. So with the principles that banks firmly hold, all forms of operations must be based on morals, ethics and honesty. The interest-based operational system implemented by conventional financial institutions has drawn controversy among Muslim intellectuals. This controversy is due to the confusion of opinion regarding the law of bank interest itself. One group says that bank interest is haram because of an additional element to the loan, and this addition is deemed usury. The other group argues that bank interest is permissible because the addition of loans as a form of remuneration to the banking sector and does not include the element of usury.

Usury is forbidden in religion to prevent inequality and injustice in economic practice. Basically, interest is in addition to loans given by financial institutions or individuals that are burdensome and suppress trade opponents (customers). The form of exploitation in the concept of borrowing and borrowing is contrary to the teachings of Islam. Accordingly, Islam is very concerned about economically disadvantaged people and defends them from being exploited by the rich. Therefore, in the concept of economics, Islam teaches its believers to pay attention to the concept of humanity, community welfare and rejects elements of injustice and elements of tyranny (exploitation). Because if this does not become the basis of the teachings, there will be massive exploitation which will eventually cause a group to fall into the abyss of poverty.

Many economists have sued the conventional economic system. This lawsuit not only comes from Muslim economists but also non-Muslim economists. This is because the conventional economic system overrides the principles of equality and does not pay attention to human values, and releases economic problems from religious values. The interest system (Riba) is one factor that hinders the achievement of justice in the economic system. It is impossible for justice to be achieved if the economic system does not eliminate interest (usury) in every economic activity. So it is necessary for the economic system to pay attention to ethical, moral and religious values in every economic behavior of the community, which in the end, the economic system pays attention to the rights of individuals and groups and is not exploitative. 
Regarding the law on bank interest, Muslim scholars and intellectuals have different opinions. The first group argues that the law of bank interest is absolutely haram. The prohibition of bank interest among these circles believes that the law of interest is the same as usury. This is because there is an additional element (interest) on loan, which causes inequality between one party and another, and the strong party takes advantage of the difficulties of the needy. The second group argues that the law of bank interest is halal and cannot be justified by the law of usury. This group argues that the additional loans obtained are not consumptive and exploitative but are additional productive loans.

The legal issue of bank interest cannot be separated from the views of Indonesian Muslim economists and intellectuals such as Syafrudin Prawiranegara and M. Syafii Antonio.

Syafrudin Prawiranegara is a unique economist since he has never had a proper institutional education. Syafruddin Prawiranegara is of the opinion that bank interest does not include usury because additional loans are a form of compensation for services and customer administration costs to banks that have provided loans. The istinbath legalized by Syafruddin Prawiranegara uses a modern-contextual interpretation approach. To interpret a verse, it is necessary to understand the context of the verse so as not to rush to identify that bank interest is usury. According to Syafruddin Prawiranegara, the legal context of usury in the Qur'anic verse is closer to trading that causes losses. Meanwhile, the concept of borrowing or credit carried out in banking is not a form of usury if it is contextualized from the Qur'anic verse because the term usury does not apply to the context of lending in financial institutions, especially banks, which incidentally are modern financial institutions. The opinion expressed by Syafruddin Prawiranegara cannot be separated from the genealogy of his thoughts, namely Fazlurrahman and Ahmad Hassan (Prawiranegara, 2011).

M Syafii Antonio, a Muslim intellectual and also an Indonesian economist, has the opinion that the bank interest law is haram. His conception of prohibiting bank interest is because the behavior of lending money in Islam is something that is not allowed. In determining the law on bank interest, M Syafii Antonio uses a normative religious approach with ushul fiqh and economic methods. To analyze the law of bank interest, M Syafii Antonio analyzed it using the argumentative method, qiyas, looking for Ilat and benefit and using the empirical method (Antonio, 2019).

Based on the description above, it is clear that there is a difference of opinion in determining the law on bank interest between Syafruddin Prawiranegara and M Syafii Antonio. The difference of opinion is a natural thing in the study of thought, the things that underlie the difference of opinion between the two are: historical. Both the epistemological basis used when establishing law and genealogical distinction.

Judging from the differences of opinion regarding usury and bank interest, the author argues that the legal issue of interest is a complex and unavoidable problem. Therefore, the complexity of the legal issue of bank interest is always attractive to dive into the law of bank interest related to usury from the perspective of Syafrudin Prawiranegara and M. Syafii Antonio further. 
Based on the description above, the research is focused on examining the views of Syafrudin Prawiranegara and M. Syafii Antonio with the title "Comparative Study of Bank Interest Law from the perspective of Syafrudin Prawiranegara and M. Syafii Antonio." Accordingly, the goal of this study was to discover Syafrudin Prawiranegara's and M. Syafii Antonio's views, as well as the contrasts and similarities between them, as well as their backgrounds.

\section{Literature Review}

Riba is an additional transaction/payment, which is forbidden based on the Quran, Sunnah and ijma ' (Rohmansyah, 2017). The prohibition of usury in the Qur'an appears in four different stages. The first stage is Q:S Ar-Rum: 39. At this stage, it emphasizes that interest cannot increase welfare, both for individuals and for the state (national). The second stage is QS An-Nisa: 61. This stage reminds Muslims to comply with the prohibition on taking an interest in the previous stage. The third stage is QS Ali-Imran: 130. This stage warns Muslims not to collect interest if they want to succeed in life. The last stage is QS Al-Baqarah: 275-280. This stage shows the difference between trade and usury, which then shows that the practice of usury destroys the welfare of a nation (Arif, 2018).

In contemporary fiqh studies, it prohibits unfair forms of increasing wealth. One prohibited source of increasing wealth is receiving a monetary advantage in a business transaction without providing a fair reward. Riba represents in the Islamic value system a major source of profit that is not permitted by the Islamic Shari' $a$ and is already present in the Qur'an and Sunnah (Chapra, 1985).

Riba is forbidden in Islam not without reason and reason. Riba is forbidden to have its own wisdom. The wisdom of forbidding usury is; preventing human beings from entering the abyss of misery and poverty because the addition of usury does more harm than good (Syaikhu et al., 1981).

Interest is the amount of money paid or calculated for the use of capital. This amount, for example, is expressed by a level or percentage of capital related to it which is now often known as the capital interest rate (Muhammad, 2000).

In a liberal view, interest is an appropriate reward for capital, and the rate of interest is determined by economic conditions free as much as the pricing of existing goods is determined by demand and supply (Rivai \& Arifin, 2010).

In banking studies regarding bank interest, there can be differences of opinion between jurists and Islamic economists. One opinion state that bank interest is included in usury because there are additional elements that occur in practice. Another opinion says it is not haram (not usury) because there are no elements of injustice and exploitation. This difference could be due to differences in the method of ijtihad and interpretation of each individual, which then gives birth to different products of thought.

Firdaus, in his research entitled "Differences in the Views of the Fuqaha Concerning Bank Interest and Riba," states that the difference in the views of the Fuqaha is due to the difference in paradigm between the textualists and the contextualists. Textual circles say 
that bank interest is haram because of its illat. Illat contained in bank interest has an additional element in accordance with the meaning contained in the phrase usury itself because only the principal capital can be taken. Then the contextualists say that bank interest is not haram. It is due to the prohibition of usury (the existence of elements of exploitation and injustice) (Firdaus, 2019).

To carry out ijtihad to determine the law on bank interest, Syafruddin Prawiranegara first examined and understood the function of money. In contrast, for Muhammad Syafii Antonio, it is necessary to know and understand the stages of decreasing the verse about usury comprehensively.

\section{Methodology}

The researcher applied the library research, in which this research collects, reads, records, and analyzes books or literature written by Syafruddin Prawiranegara and M. Syafii Antonio as research objects. This qualitative research with descriptive-comparative nature described the thoughts of Syafrudin Prawiranegara and M. Syafii Antonio systematically and objectively. The last step was by comparing and finding out their opinion regarding the Law of Bank Interest.

\section{Result and Analysis}

\subsection{Results}

\section{Syafruddin Prawiranegara}

Syafruddin Prawiranegara, or in modern spelling Syafruddin, is one of the national figures who contributed to pioneering and defending Indonesia's independence as well as one of the Indonesian Muslim economists. Syafruddin Prawiranegara was born in Anyer Kidul Serang Banten on February 28, 1911. Syafruddin Prawiranegara has the nickname "Kuding" which is taken from the name Syafruddin or Udin (Sriyanto, 2017). As a child, Syafruddin Prawiranegara had a fondness for reading adventure stories similar to Robinson Crusoe. His love of reading and adventure showed that in the future, Syafruddin wanted to become a big man (Aning, 2005).

Syafruddin Prawiranegara was born to Raden Arsjad Prawiraatmadja and Noeraini. Syafruddin Prawiranegara's family comes from a priyayi family and a religious family. The blood that flows in Syafruddin's body is a mixture of Banten-Minangkabau blood. Raden Haji Chatab Aria Prawiranegara or better known as Patih Haji, who is none other than the grandfather of Syafruddin Prawiranegara, was a governor of Serang Regency in 1879-1884. Patih Haji married twice, from the first marriage gave birth to four children and the second marriage also gave birth to four children. It was in this second marriage that Raden Arsjad Prawiraatmadja was born, who was none other than the father of Syafruddin Prawiranegara.

Syafruddin Prawiranegara was raised in a religious family. At the age of 4-5, Syafruddin Prawiranegara was taught to fast even though it was not full for one day and then gradually full one day. Syafruddin Prawiranegara received religious education from his father's brother. Although large from a noble family, Syafrudin Prawiranegara's extended family is 
known to be close to the people. Because of Raden Arsjad Prawiraatmadja's close relationship with the people, he was exiled to Ngawi in 1924.

Before moving to Ngawi following his father, Syafruddin Prawiranegara had entered the ELS school (Europeesche Lagere School), which is a special school for Dutch people and Indonesian aristocratic families at the same level as school base. When he moved to Ngawi, Syafruddin Prawiranegara had taken the seventh grade, and his first education was completed in Ngawi.

After graduating from basic education, Syafruddin Prawiranegara wanted to enter the HBS (Hoogere Burger School) school because, at that time, HBS was considered a junior high school with the highest quality. However, if Syafruddin Prawiranegara wanted to continue his education at HBS, he had to live in Surabaya, Bandung and Jakarta because only in those three cities HSB was located. Knowing this, the headteacher of ELS Ngawi suggested that Syafruddin continue his junior secondary education at MULO (Meer Uitgebreid Lager Onderwijs), located in Madiun Regency. In addition to the relatively low cost of education, ELS graduates do not need an entrance exam such as typing in HBS, and the quality of education at MULO is also equivalent to HBS. The difference only lies in the length of education. Apart from that, MULO graduates can also continue their education to AMS (Algemene Middelbare School) equivalent to a general high school or above. The advice given by the headteacher of ELS Ngawi was accepted by Syafruddin's father and put him in MULO in Madiun in 1928.

After graduating from MULO Madiun, Syafruddin Prawiranegara continued his education to AMS part A in Bandung in 1931. Since the second grade of ELS, Syafruddin Prawiranegara has shown interest in studying literature. Since finishing Robinson Crusoe's book, he has become fond of reading. All books are devoured.

After graduating from AMS, Syafruddin Prawiranegara wanted to continue his education at a literary college, but at that time, Indonesia did not have a special literary college. At that time, a new literary college was in the colonial country (the Netherlands). Due to limited funds, Syafruddin Prawiranegara could not continue his dream of entering a literary college. Finally, in 1931 Syafruddin Prawiranegara entered RHS (Rechts Hoge School), which is equivalent to a law school.

While still a student at RHS, to hone his soft skills, Syafruddin Prawiranegara joined USI (Unitas Studiosorum Indonesiensi), which is a non-political student organization, but this organization is a forum for high school students who do not see the social background of its members. In this organization, Syafruddin Prawiranegara is known as a socialist group, and by his friends, Syafruddin is given a role in political matters. While still serving at USI, Syafruddin was very influential and had many roles. Even after graduating from RHS, Syafruddin was still appointed as an honorary member of USI (Sriyanto, 2017).

His great interest in socialism, communism, politics, economics and law influenced his career. This was marked by the inclusion of Syafruddin Prawiranegara as a member of the KNIP (Central Indonesian National Committee). 
Background family, interests and education of Sjafruddin Prawiranegara affected his career. Accordingly, he had membership in the organization or administration as follows:

1. After graduating from RHS, Sjafruddin Prawiranegara applied for jobs at PPRK (Perkumpulan- Eastern Radio Association) was placed in the position of administrator and concurrently as editor of Soeara Timoer (PPRK Magazine).

2. Officer of the Ministry of Finance at the tax office of Kediri (1940-1942).

3. Employees of the Ministry of Finance as Head of the Kediri Tax Office and transferred to the Bandung Tax Office as head of the tax office.

In addition to occupying strategic positions, Syafruddin Prawiranegara is also known as a productive figure. Every time he gets an invitation to give a lecture on the pulpit, in front of students or people, he always attaches his writings as study material. Some of Syafruddin Prawiranegara's gifts include:

1. (1946) Speech of the Minister of Finance when the Republic of Indonesia was ratified: Soeara Merdeka.

2. (1948) Our Politics and Revolution, BP Indonesia Raya.

3. (1951) Historical standings and victories, Suara Masjumi Party.

\section{Syafruddin Prawiranegara's thoughts on Riba and bank interest}

Syafruddin Prawiranegara is an Indonesian Muslim economist who has never attended Madrasah/Islamic boarding school education. He got his religious education when he studied the Koran as a child and through the books he had read.

If Muslim economists during his time read Arabic literature, it was different from Syafruddin Prawiranegara. Because of his limitations in reading the yellow book (Arabic book without syakal), to deepen Islamic studies, he reads translated literature in Dutch and English. To explore Islamic scholarship, Syafruddin Prawiranegara met the works of Islamic scholars from the Indian subcontinent. Syafruddin Prawiranegara's thoughts on Islam were heavily influenced by the thoughts of A. Hassan and Fazlurrahman.

In discussing usury and bank interest, Syafruddin Prawiranegara argues that in the Qur'an, hadith and according to ratios or logic, there is no reason for the prohibition of normal bank interest, and the margin has been determined in advance based on the contract between the lender (the creditor) and the lender. In borrowing (the debtor), bank interest can be said to be usury when the amount is doubled (ad'afan Muda'afan).

In terminology, the meaning of usury, according to Syafruddin Prawiranegara, is profit obtained in the form of money, goods and services by violating norms and ethics. Another meaning of usury is; every additional profit from ordinary buying and selling activities, but one of the parties is forced to accept a sale and purchase contract because of his weak position (needs). The buying and selling activity is not a clean sale because one party is forced to accept because of his weak position. Syafruddin calls this Exploitation de i'homme 
par I'homme (Oppression and extortion of humans by fellow humans) (Prawiranegara, 2011).

The istinbath method (Stipulating a law) regarding usury and bank interest, Syafruddin Prawiranegara uses the Tafsir Bil Ma'tsur method or uses the Qur'an and the prophet's hadith as a tool to interpret the verses of the Qur'an. The Qur'anic arguments relating to usury taken by Syafruddin Prawiranegara are; Al-Baqarah: 2:275. Ali-Imran: 3:130 and AnNisa: 4:29.

Regarding the law on bank interest, according to Syafruddin, it is necessary to distinguish and understand in advance the meaning of rent and moneyer or, in usury, between service fees and usury (Prawiranegara, 2011). Rent is interest or interest whose margin has been determined in advance and is not exploitative. For Syafruddin, if interest is the same as usury, all economic transactions must be carried out in cash even though the delivery of goods is carried out in the future. In this case, people who have a weak economy are disadvantaged by this transaction pattern because they cannot afford to buy goods in cash and have to use the credit system (Prawiranegara, 2011).

For Syafruddin, interest is not synonymous with usury but with rent. However, it is different if someone rents out his goods with high rent because he uses and takes advantage of the circumstances and harms what is being rented. The legal rent turns into usury because there is an exploitative form (Prawiranegara, 2011).

The difference of opinion regarding interest, for Syafruddin, is a form of error in interpreting and interpreting the function of money as a means of production. If it is examined through ratios, Allah SWT does not prohibit us from taking service fees from leasing and borrowing money from people who need the money as trading and production capital. For Syafruddin, money as a means of trade can be loaned and rented the same as other means of production, and we may take profit or return services from the money (interest rate) (Prawiranegara, 2011).

The law of bank interest, according to Syafruddin Prawiranegara, is halal. This matter is based on the meaning of $\bar{I}$ and the function of money itself. For Syafruddin, interest cannot be equated with usury since the interest set on buying and selling or lending and borrowing is a common thing in trading activities as well as service fees. In addition, for Syafruddin, interest cannot be separated from every economic activity and has become human nature itself. However, the law of interest, which was originally lawful, can turn out to be unlawful when one of the people who carry out buying and selling or borrowing transactions abuses his opponent's difficulties and takes a too high interest.

Interest-free banks are a contradiction in terms of the words. Basically, interest-free banks cannot survive because the bank's income is obtained from the difference between the interest paid and the interest received (Prawiranegara, 2011).

All institutions or entities that claim to be "interest-free banks" need to be examined first from where they get their money and how to manage their money to make a profit. So, after finishing the study, we will get the following conclusions: 
1. "Interest-free bank" actually attracts and pays interest from customers, but its name is changed to a service fee or something else.

2. The bank is not a bank because it does not borrow and lend money. It could be that the agency or institution is an investment agency or institution and certainly not a bank if it does not meet the requirements and characteristics of the bank (Prawiranegara, 2011).

Misinterpretation of interest (interest) and identifying it with usury is a blurring of our views and goals about true Islam. Interest (Interest) obtained from trade or loans is lawful. But the profits that are obtained excessively by violating the ethical concept of humanity and destroying God's nature. This is the true nature of usury, and this is what is forbidden by Allah SWT (Prawiranegara, 2011).

\section{Syafii Antonio}

Nio Guan Chang, more commonly known as Muhammad Syafii Antonio, is an Indonesian Muslim economist. Syafii Antonio was born in Sukabumi on May 12, 1967 to Nio Sen Nyau and Liem Soen Nio (HJ. Suniah Badrahalim). His father, Nio Sen Nyau, was a priest from the Tri Dharma religion, and his mother was an expert in sinse who eventually followed in Syafii Antonio's footsteps to convert to Islam.

Syafii Antonio's family is a religious family, and every member of his family is free to choose any religion other than Islam. Because of that freedom, Syafii Antonio converted to Protestant Christianity and changed his name to Pilot Sagara Antonio. Syafii Antonio's entry into Protestant Christianity was welcomed by his father, but his father would be very angry when Syafii Antonio converted to Islam. This is due to the bad image of Islam in the view of Syafii Antonio's father. While studying Islam, apart from seeing the reality of his environment, Syafii Antonio also started reading comparative religion books and books related to Islam. In order to get an objective argument in studying Islam, Syafii Antonio uses three approaches as analytical tools. The three approaches are the historical approach (history), practical approach (natural), and rational reasoning approach (reason).

Immediately, Syafii Antonio once found it very difficult to understand Islam, but after he had the concept to separate Islam as a system and Muslims who run the system. This is one of the factors that Syafii Antonio has deepened his knowledge of Islam and denies the bad image of Islam in his father's view. Syafii Antonio's father admits that the teachings of Islam are good, but Muslims do not reflect the values and perfection of their religion. For Syafii Antonio's father, Muslims are synonymous with backwardness and crime. Poverty and corruption. Thus, Syafii Antonio became increasingly interested in Islam because he heard the bad image of Islam from his father. Previously, Syafii Antonio had learned about Islam through his neighborhood and school environment.

At the age of seventeen, when he was still in high school. Syafii Antonio departed from Sukabumi to Bogor to attend the recitation and study Islam. At that time, Syafii vowed to enter Islam, which was guided by KH. Abdullah bin Nuh Al-Ghazali later changed his name from Pilot Sagara Antonio to Muhammad Syafii Antonio. 
To study Islam and learn Arabic, Syafii Antonio entered the An-Nidzom Islamic Boarding School, Sukabumi. After graduating from high school (SMA), Syafii Antonio continued his education at the Bandung Institute of Technology (ITB). It did not last long before he moved to IAIN Syarif Hidayatullah Jakarta or what we now know as UIN Syarif Hidayatullah. Syafii Antonio's education at IAIN Syarif Hidayatullah only lasted for two weeks, and this was not because Syafii Antonio was expelled by the campus, but Syafii Antonio wanted to study abroad and deepen the teachings of Islam.

Syafii Antonio entered the Sharia faculty of the University of Jordan in 1986 and finished in 1990 with a Bachelor of Art in Islamic Studies (Main Degree) Economics and Statistics (Minor Degree), Syafii Antonio took the master's degree at the International Islamic University of Malaya (IIUM) specializing in Islamic Economics (Wijaya, 2019). Syafii Antonio's education does not only stop at the master's level, but Syafii Antonio continues his studies to get a Doctoral Degree (Ph.D.) with a concentration in Micro Finance at the University of Melbourne, Australia. In addition, Syafii Antonio has also conducted visiting research at Oxford University, England and Al-Azhar University, Egypt.

As an expert in Islamic economics and finance, Syafii Antonio has held many positions related to finance and religion, including;

1. One of the first Islamic Founding Banks (Bank Muamalat) in Indonesia (1993).

2. One of TAZKIA's Founding STEI (Islamic Economics College)

3. Sharia Bank Expert Committee for Bank Indonesia

Apart from being an economic and financial practitioner, Syafii Antonio is also productive in giving birth to gifts and providing literacy strengthening to the community. Some of Syafii Antonio's gifts include;

1. Muhammad SAW: The Super leader Super Manager

2. Islamic Bank from Theory to Practice

3. What and how is an Islamic bank

\section{Syafii Antonio's Thoughts on Riba and Bank Interest}

As an expert of Islamic economics in analyzing the fiqhiyyah law, Antonio used the argument of the Quran and the Sunnah of Prophet Muhamad SAW to do istinbath. Antonio's method involved maslahah mursalah and Istihsan, which in turn can produce an objective examination. Syafii's thoughts on Sharia were greatly influenced by the thoughts of Yusuf Qardhawi and Imam Ar-Razi. Syafii Antonio thinks that usury is illegal. The basis of usury prohibition can be seen from the level of usury prohibition. The prohibition of usury is not only one stage but four stages.

In addition to the verses of the Qur'an and the Hadith of the Prophet Muhammad SAW as bayan, Syafii Antonio also uses the results of ijtihad/fatwa of Islamic organizations (Community Organizations) as a reinforcement of the law of usury and bank interest. In addition to the results of ijtihad from Muslim organizations around the world, M. Syafii 
Antonio also highlighted the prohibition of flowers from the Non-Muslim side, such as Jewish circles, Greek and Roman circles, and Christian circles.

To find out more about the prohibition of bank interest, according to M. Syafii Antonio, we need to know the difference between investing and paying interest. Investment is a business activity that contains risk due to the element of uncertainty. Therefore the return is not fixed and uncertain, unlike the case with interest on money whose activities are less risky, because the return that contains interest is relatively fixed and certain. Muslims are encouraged to invest because it can encourage people to increase business productivity, and it is forbidden to pay interest. (Antonio, 2019)

In addition to understanding the difference between investing and paying interest on money, M. Syafii Antonio also suggests knowing the difference between money debt and goods debt. According to M. Syafii Antonio, debts arising from borrowing and borrowing money should not be subject to additional fees, except for certain reasons such as; Notary fees, procurement of stamps and feasibility studies. Apart from these three conditions, additional costs are not allowed, especially unclear ones, such as inflation and deflation. Likewise, with debts that occur due to borrowing and borrowing goods, the only costs that may be taken are the selling price which includes; agreed cost and profit. When the price rises after the agreement, this is not allowed and is included in the category of usury fadl (Antonio, 2019).

The prohibition of usury and bank interest is clearly stated in the arguments of the Qur'an and the sunnah of the prophet Muhammad SAW, but there are differences of opinion and scholars give reasons for justifying interest on money loans, including:

1. In the State of Emergency; According to Syafii Antonio, for us to understand the meaning of emergency, it is necessary to discuss and understand the meaning of emergency comprehensively so that it is in accordance with the emergency referred to by the Shari'a and not an emergency that we understand in everyday terms (Antonio, 2019).

2. Multiply; In this context, many arguments state that interest is said to be usury if there is an additional double in it. This is based on the meaning and misinterpretation of QS Ali-Imran: 3:130.

3. Taklifi Legal and Legal Entities; Scholars and economists who justify bank interest argue that, at the time of the Prophet Muhammad SAW, financial institutions did not yet exist. Therefore, financial institutions or banking at this time are not subject to taklifi law. However, it contained historical and technical ambiguities and weaknesses (Antonio, 2019).

When bank interest is accepted as part of the economy, and the law is not equated with usury, according to Syafii Antonio, it will hurt society and individuals. There are at least four warnings from Imam Al-Razi quoted by M. Syafii Antonio explaining why Islam forbids the interest system (Antonio, 2019). 
1. Stealing the wealth of others

2. Damaging morality

3. Breeding seeds of hatred and enmity

4. The rich are getting richer, while the poor are getting poorer

\subsection{Analysis}

\section{Differences and Similarities of Thought}

The similarities between Syafruddin Prawiranegara and M. Syafii Antonio can be seen from the arguments used as the basis for ijtihad that gave birth to legal products. The basis of Hujjah used by both of them is usury verses (An-Nisa: 4:29, Ali-Imran: 3:130 and AlBaqarah: 2:278-279) contextualized according to their respective istinbath methods.

In this study, there are many differences between Syafruddin Prawiranegara and M. Syafii Antonio, a very striking fundamental difference between the two economists can be seen from the socio-historical and genealogical thinking of the two. Syafruddin Prawiranegara is an economist who has never attended a madrasa and his thoughts on Islam, especially usury and bank interest, were self-taught and more or less, his thoughts were derived from his genes; Fazlurrahman and A. Hassan. On the other hand, M. Syafii Antonio is a convert to Islam who, after graduating from high school, attended a madrasa and university with Islamic values. His way of thinking about bank interest is similar to his gene of thought; Yusuf Qardhawi and Imam Ar-Razi.

In addition to socio-historical and genealogical, the differences of thought between Syafruddin Prawiranegara and M. Syafii Antonio include;

\section{Istinbath Method}

In establishing a law, Syafruddin Prawiranegara uses the method of istinbath Tafsir bil ma'tsur (interpretation of verse by verse or verse by the sunnah of the Prophet Muhammad SAW). In comparison, M. Syafii Antonio uses the method of istinbath Maslahah Mursalah (Deeds that contain good values) and Istihsan (consider good). In setting the law, M. Syafii Antonio uses all the verses of riba that descend in four stages, a comprehensive understanding of the level of descent and the reason for the descent of the verse (Asbabun Nuzul) of each verse will send us to the absoluteness of the prohibition of riba with all its forms.

\section{Results of Ijtihad (Product of Law)}

Syafruddin Prawiranegara argued that the law of interest is permissible, provided that both parties have agreed to the interest margin withdrawn. However, if only one party agrees while the other party does not, and there is an exploitative element in it, then the law of interest that was originally halal turns into haram.

M. Syafii Antonio thinks that the law is absolutely illegal. To know more about the prohibition of bank interest, M. Syafii Antonio explained the importance of knowing the difference between investing and making money and then knowing the impact when interest is allowed 


\section{Conclusions and Recommendation}

\subsection{Conclusion}

Based on the results of the research that has been analyzed by the researcher regarding the comparative study of bank interest in the perspective of Syafruddin Prawiranegara and M. Syafii Antonio, it can be concluded;

1. According to Syafruddin Prawiranegara, interest cannot be equated with usury. Therefore, the law of interest is halal. Buying and selling transactions or lending and borrowing must be based on consensual interest as well as in attracting interest. If someone who conducts buying and selling or lending and borrowing transactions takes advantage of the difficulties of their partnership and sets a higher price, then the law of interest, which was originally halal, turns into haram. The difference of opinion that occurs regarding interest is a misinterpretation of scholars regarding the function of money itself. For Syafruddin to determine the law of interest, it is necessary to study more deeply the function of money. The basis of Hujjah Syafruddin Prawiranegara in studying usury and interest is QS Al-Imran 130, QS An-Nisa 29, QS Al-Baqarah 275 and several hadiths, while the istinbath method was applied in conducting ijtihad with the interpretation method of bil ma'tsur (interpreting the verse with verse or verse with the hadith of the prophet).

2. According to M. Syafii Antonio, interest is haram and is the same as usury. This opinion is based on the istinbath method Maslahah mursalah and istihsan, a comprehensive understanding of the stages of the revelation of usury verses and the reason for their descent (Asbabun Nuzul) is the basis for the argument for the prohibition of interest, and the law is equated with the law of usury. In the opinion of M. Syafii Antonio, in order for us to know more clearly the law of bank interest, it is necessary to first distinguish between investment and interest-bearing activities. M. Syafii Antonio's opinion about the prohibition of bank interest is also the same as the provisions of Indonesian Muslim Ormas (Society Organizations) and other non-Muslim religious and non-Muslim institutions. If interest is allowed, it will have an impact on social and economic conditions. Imam Ar-Razi warned the Muslim community and explained why we should support the prohibition of flowers for four reasons: Stealing the wealth of others, Damaging Morality, Breeding seeds of hatred and enmity, and the rich getting richer and the poor getting poorer.

3. After the thoughts of the two figures are analyzed, there are similarities between the two in terms of the evidence for the usury verse used. The difference in the thoughts of the two figures lies in the istinbath method, the basic understanding of usury, and the results of ijtihad (law/product of thought) from both of them.

\subsection{Recommendation}

Regarding the comparison of Syafruddin Prawiranegara and M. Syafii Antonio regarding the law of bank interest, some advice and inputs to all Islamic economics students in general, Islamic bank practitioners, in particular, are as follows: 
1. All Islamic economics students need to explore and become role models in increasing Islamic economic literacy among the community and be more observant in choosing anything, especially banking practices.

2. For future researchers, it is hoped that the results of this study can be used as reference material in the future regarding the perspective of Syafruddin Prawiranegara and M. Syafii Antonio bank interest.

3. For the Sharia Economics Study Program, it is hoped that this research can be used as an archive of theoretical thoughts, and the Sharia Economics Study Program in the future will provide students with an open space in the philosophical-practical study of Islamic economics.

4. For Financial Institutions, it is necessary to examine more deeply the differences of opinion that occur regarding the operational system of financial institutions, which ultimately lead to caution in c2onducting banking transactions.

\section{References}

Aning, F. (2005). 100 Tokoh yang Mengubah Indonesia: Biografi Singkat Seratus Tokoh Yang Paling Berpengaruh dalam Sejarah Indonesia di Abad 20. In Narasi (Cetakan Pe). Narasi.

Antonio, M. S. (2019). Bank syariah: dari teori ke praktik (Cetakan-30). Gema Insani.

Arif, M. (2018). Filsafat ekonomi islam. Fakultas Ekonomi dan Bisnis Islam.

Chapra, M. U. (1985). Towards a Just Monetary System. Islamic Foundation.

Firdaus, R. (2019). Perbedaan Pandangan Fuqaha Ihwal Bunga Bank dan Riba. Ekonomika Syariah: Journal of Economic Studies, 3(2), 47-60. https://doi.org/10.30983/es.v3i2.2150

Muhammad. (2000). Lembaga-lembaga keuangan umat kontemporer. UII Press.

Prawiranegara, S. (2011). Ekonomi dan keuangan : makna ekonomi Islam Jilid 2 (A. Rosidi (ed.); Cetakan ke). Pustaka Jaya.

Rivai, V., \& Arifin, A. (2010). Islamic Banking: Sistem Bank Islam Bukan hanya Solusi Menghadapi Krisis Namun Solusi Dalam Menghadapi berbagai persoalan perbankan \& ekonomi global : sebuah teori, konsep, dan aplikasi. Bumi Aksara.

Rohmansyah. (2017). Fiqh Ibadah dan Mu'amalah (Cetakan-1). LP3M Universitas Muhammadiyah Yogyakarta.

Sriyanto, M. P. I. (2017). Sang penyelamat republik. Pro-U Media.

Syaikhu, Ariyadi, \& Norwili. (1981). Fikih Muamalah Memahami Konsep dan Dialektika Kontemporer. In K-Media (Issue 1).

Wijaya, R. (2019). Biografi Muhammad Syafii Antonio. Bio.or.Id. http://bio.or.id/biografimuhammad-syafii-antonio/ 